\title{
Morphodynamic conditions of heavy metal concentration in deposits of the Vistula River valley near Kępa Gostecka (central Poland)
}

https://doi.org/10.1515/geo-2020-0058

received September 27, 2019; accepted January 14, 2020

\begin{abstract}
The influence of morphodynamics of individual river valley zones on the anthropogenically induced distribution of heavy metals in the Małopolska Gorge of the Vistula River near Kępa Gostecka was studied. Based on the analysis of cartographic and geological mapping data, several floodplain features were distinguished. For each feature, lithological analysis of the deposits was carried out. It comprised determination of clay content, organic matter, carbonates and iron oxides and hydroxides, as well as analysis of heavy metal concentration. The investigations show that the concentration of heavy metals in floodplain surface deposits is strictly linked with the variability of depositional environments, which reflected in the intricate feature pattern. The highest contents of heavy metals have been found in the deposits of the contemporary floodplain, stagnation zones of floodwaters, oxbow lakes buried under floodplain or organic deposits and escarpment foot back swamps, while the lowest in deposits of the Pleistocene terrace and slope wash zones. Variability of floodwater dynamics modelling the floodplain surface is associated with the specific geological setting of the Vistula River valley stretch analysed.
\end{abstract}

Keywords: River valley, floodplain morphogenesis, alluvial deposit, trace elements

\section{Introduction}

The content of heavy metals in surface deposits is a significant indicator for assessing environmental

\footnotetext{
* Corresponding author: Agnieszka Katmykow-Piwińska, Faculty of Geology, University of Warsaw, Żwirki i Wigury 93, 02-089 Warsaw, Poland, e-mail: a.kalmykow-piwinska@uw.edu.pl

Ewa Falkowska: Faculty of Geology, University of Warsaw, Żwirki i Wigury 93, 02-089 Warsaw, Poland
}

conditions, particularly the degree of their transformation under the influence of natural and anthropogenic factors $[1,2]$. The general sources of heavy metals in alluvial deposits are well recognised. Usually, their presence in a fluvial environment is linked with mining activities within the river basin [3,4], the concentration of industry $[5,6]$, intensive agriculture $[7,8]$, the functioning of urban agglomerations [7] and remobilisation of older, strongly polluted deposits $[9,10]$.

The increased content of trace elements in both river water and deposits of the Vistula River comes from mining areas of Upper Silesia and from urban areas located in the upper parts of the analysed stretches [3,11-14].

In the fluvial environment, the transportation volume of heavy metals depends on their physical-chemical properties and on the dynamics and chemical properties of the river water environment $[7,9]$. These elements are transported in a dissolved form, as aggregates precipitated from solution and bound with mineral and organic components of the river bedload. From 90 to $99 \%$ of the transported elements are bounded to particles that are less than $0.063 \mathrm{~mm}$ in size [15], which strictly relates their concentration to the dynamics of the transportation and depositional environment. These dynamics influence the lithology of the deposited sediments (the content of clay minerals and their mineral composition, the content of organic matter, carbonates, iron oxides and hydroxides), as well as the possibility of remobilising the earlier accumulated heavy metal load [9,16-20].

The particle fractions of 0.063 and $1.0 \mathrm{~mm}$ are commonly analysed for heavy metal content [4,6,21-23]. Both fractions often show similar trends in the distribution of trace element concentrations [13,14,24,25], although in the case of the $1.0 \mathrm{~mm}$ fraction, analyses show much greater differences of the mean of these elements [24,25].

Most studies of heavy metal contents in deposits are focused on the river channel zone [11,18,24-31]. Only a few reports refer to the heavy metal distribution in floodplain deposits and on the influence of fluvial processes on the spatial distribution of these elements [4,6,13,32]. Besides, 
these reports are related to the distribution of heavy metals in flood facies, depending on the distance from the source of pollution $[4,8]$, distribution of metals in flood facies along the entire river course (from source to mouth) [10,33], relationship between metal concentration and chemical properties of the deposits, in which they occur $[6,34]$, and heavy metal concentration depending on the distance measured from the river channel $[13,21,22,35]$. In turn, studies on the relationship between heavy metal concentration and the pattern of floodplain features, representing the so-called geomorphological-geochemical approach, are relatively few [1]. In our opinion, such an approach could better explain the distribution of anthropogenically induced heavy metal concentration in alluvial deposits. Hence, this work focused on determining the degree to which the variability of the dynamics of contemporary fluvial processes influences the concentrations of trace elements in alluvial deposits forming the bottom of the Vistula River valley in the vicinity of Kępa Gostecka.

\section{Study area}

The analysed stretch $(325-339 \mathrm{~km})$ of the Vistula River valley is located between Kępa Piotrawińska and Zakrzów (Figure 1) and comprises a part of the Małopolska Gorge of the Vistula River [36,37]. The shape of the valley is strictly linked to variable resistance of the eroded Upper Cretaceous rocks: siliceous marls, gaizes, marls and limestones [38-40]. In stretches where the valley is carved in rocks that are more resistant to erosion the valley is narrower and has distinctly steeper slopes [41].

The analysed stretch is referred to as free mature [42] There, the dynamics of the erosional and depositional processes in the river freely reacted to the changes of the hydrogeological regime in the latest Pleistocene and in the Holocene, developing the observed Pleistocene overbank terraces and the bipartite floodplain (Figure 2). Upper accumulation surfaces were formed by the braided and overloaded Vistula River, with a significant contribution of slope processes [43].

The development of the contemporary floodplain commenced with the Late Vistulian climate warming, which caused rapid evolution of forest communities [44] and change of the hydrological regime. Surface flow decreased along with bedload supply to the Vistula River channel. The meandering Vistula River incised into a surface composed of Pleistocene alluvia forming the floodplain horizon, which is reflected in traces of channel migration visible in the landscape and crescent-shaped oxbow lakes. Lower dynamics of fluvial processes in this interval are recorded through the presence of a loam layer representing flood deposits with an average thickness of 3-4 m. In the neo-Holocene, changes of the hydrological regime caused by management of the catchment area (e.g. deforestation, intensification of agriculture and introduction of root crops) resulted in both an increase in the differences between extreme flows and the transformation of the meandering river into a braided river. The overloaded river formed a new floodplain feature along the channel - a braided belt - and a wild river developed [42,45,46]. Acceleration of the change rate is linked with narrowing of the vegetation zone and introduction of root crops, which caused an increase in the supply of washout deposits and a decrease in the catchment retention. Increased dynamics of the floodwater flow zones accompanying the transformation of the Vistula River fluvial system caused a partial transformation of the floodplain surface formed during the meandering process. Dynamic floodwater flows removed fragments of loamy muds of the meandering river and caused deposition of silty and sandy floodwater deposits [47].

\section{Methods}

Lithological variability of floodplain surface deposits in the study stretch of the Vistula River valley was geologically mapped using both aerial photographs at the scale of 1:20,000, acquired in 2003, and a digital elevation model (DEM) with a resolution of 10 and $1 \mathrm{~m}$. Two hundred and fifty-nine drillings (Figure 1) were made to a depth of about $4 \mathrm{~m}$ or to the groundwater level using an Eijkelkamp liner sampler set with a diameter of $90 \mathrm{~mm}$. Eight hundred and thirty-one samples of alluvial deposits were collected for laboratory analysis. The samples were collected from each subsequent lithological layer starting from a depth of $0.6 \mathrm{~m}$ or from every $0.5 \mathrm{~m}$. The collected samples were stored in zipper storage bags.

Grain size analysis by areometric and sieve methods allowed determining the content of individual fractions, especially the clay fraction, and specifying the type of the deposits [48]. This was performed on 257 deposit samples selected on the basis of macroscopic analysis. The organic matter content was determined in selected samples based on loss on ignition at $440^{\circ} \mathrm{C}$ (following the American Standard ASTM D 2974-87). The calcium carbonate fraction in the samples was tested using the 


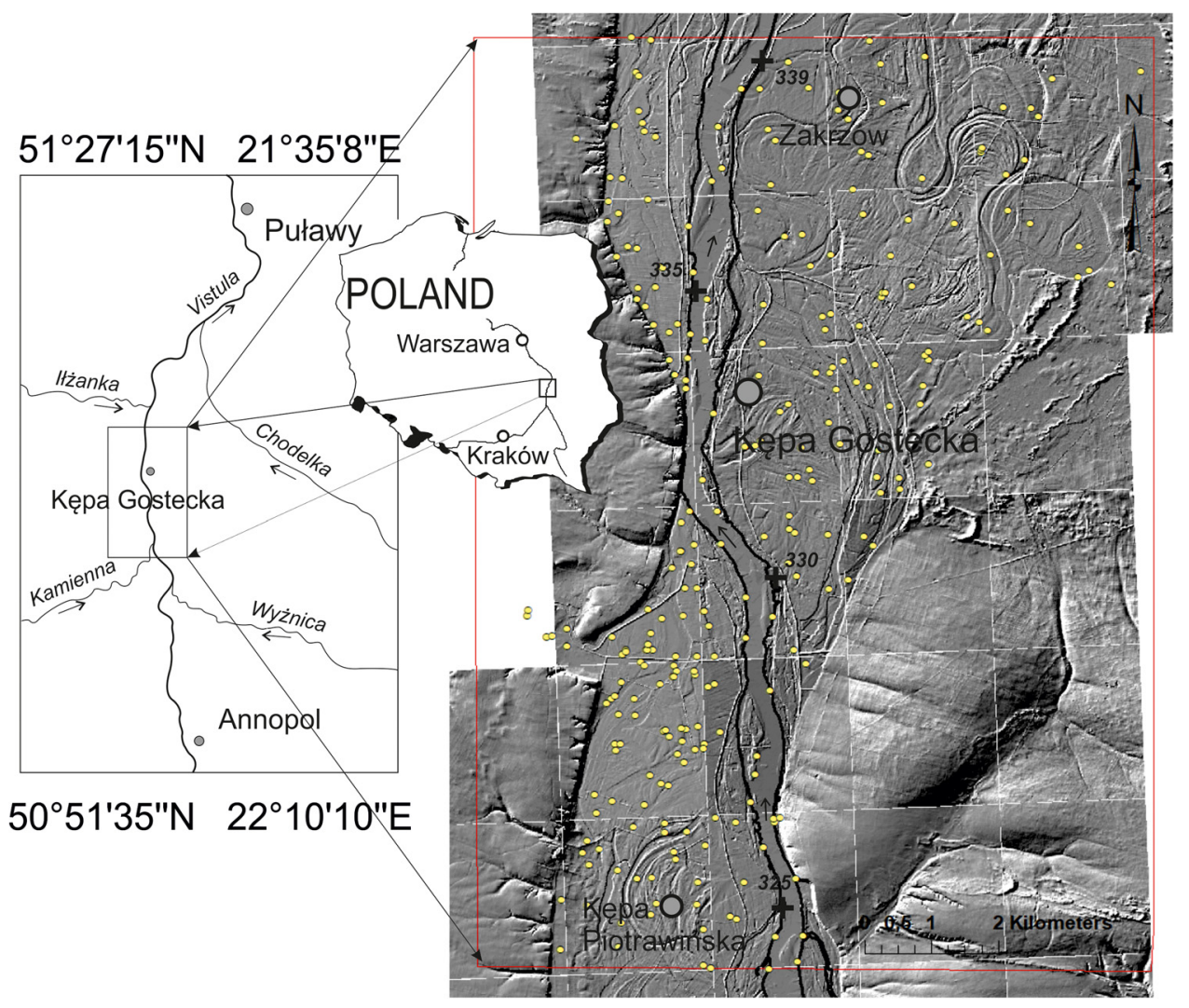

Figure 1: Location of the study area with sampling sites on a DEM image.

Scheibler method, and the iron content was analysed using the iodometric method [48].

Geochemical analyses were performed on 155 representative deposit samples: 84 from a depth of $0.6 \mathrm{~m}$ and the remaining from subsequent deeper layers. The samples were dissolved in an $\mathrm{H}_{2} \mathrm{O}-\mathrm{HF}-\mathrm{HClO}_{4}-\mathrm{HNO}_{3}$ solution (at the ratio of 2:2:1:1) [49]. Determinations of 11 trace elements ( $\mathrm{Cu}, \mathrm{Pb}, \mathrm{Zn}, \mathrm{Ni}, \mathrm{Co}, \mathrm{As}, \mathrm{Sr}, \mathrm{Cd}, \mathrm{V}, \mathrm{Cr}$ and $\mathrm{Ba})$ from the 0.063 and $1.0 \mathrm{~mm}$ fractions were made at Acme Labs (Bureau Veritas Commodities Canada Ltd) using inductively coupled plasma atomic emission spectroscopy or inductively coupled plasma mass spectrometry.

Based on cartographic analysis and field data, zones characterised by different morphodynamics have been distinguished, with typical lithological profiles attributed to each zone. Next, lithological cross-sections of the valley bottom were constructed.

Principal component analysis (PCA) and regression analysis of the contents of the clay fraction, organic matter, calcium carbonate and iron oxides and hydroxides were performed in Statistica 12 (StatSoft) to determine the factors influencing the trace element distribution. The confirmation of the differences between heavy metal concentrations in deposits of individual features was made using detrended correspondence analysis (DCA) in PAST3 and one-way analysis of variance (ANOVA). The significance of this variability was tested using the non-parametric Kruskal-Wallis statistics (Statistica 12, StatSoft). For some analyses, the data were grouped to increase sample abundance. Statistical analyses were performed for the $1.0 \mathrm{~mm}$ fraction.

\section{Results}

\subsection{Morphogenesis and lithology of the floodplain}

Based on aerial photographs and DEM analysis coupled with geological field mapping, the following 18 geomorphological zones/features were distinguished in the study stretch (Figure 2): contemporary floodplain (cf), meander plain reworked by flows of the contemporary braided river (mpr), meander plain reworked by flows of the contemporary braided river with flat and levelled surface (mpr-f), stagnation zones of floodwaters (sz), oxbow lakes buried under floodplain or organic deposits (sz-o), escarpment foot back swamps (sz-s), concentrated flow zones of floodwaters 


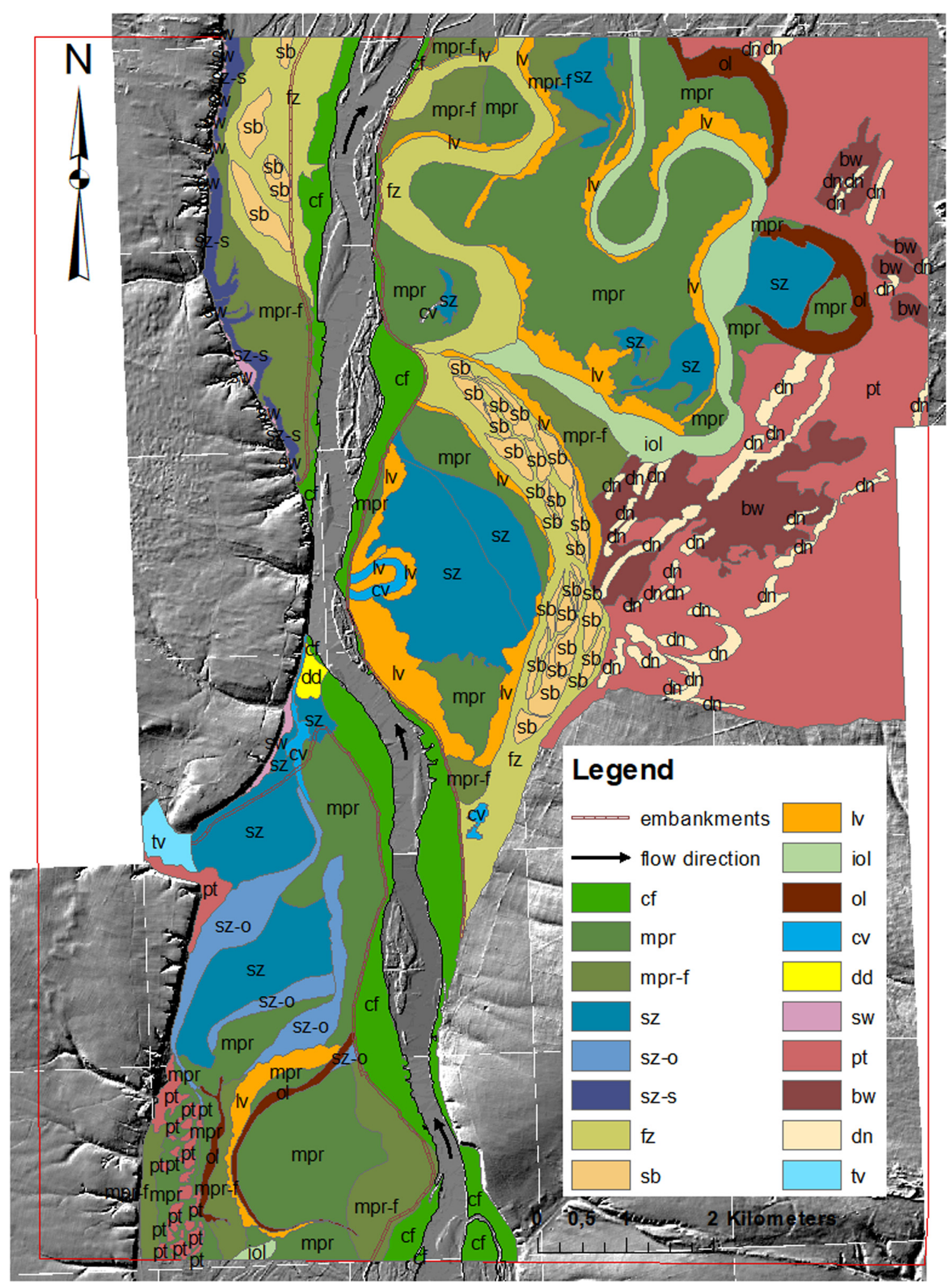

Figure 2: Floodplain features on a DEM image.

(fz), sandy bars (sb), levee deposition zones (lv), alluvial deposits infilling oxbow lakes (iol), oxbow lakes (ol), crevasses (cv), deltaic deposition zones (dd), slope wash zones (sw), Pleistocene terrace (pt), dunes (dn), blowouts on the Pleistocene terrace (bw) and tributary valleys (tv) (Krępianka valley).

The contemporary floodplain (cf) of the braided river is limited by flood embankments and occurs in the form 

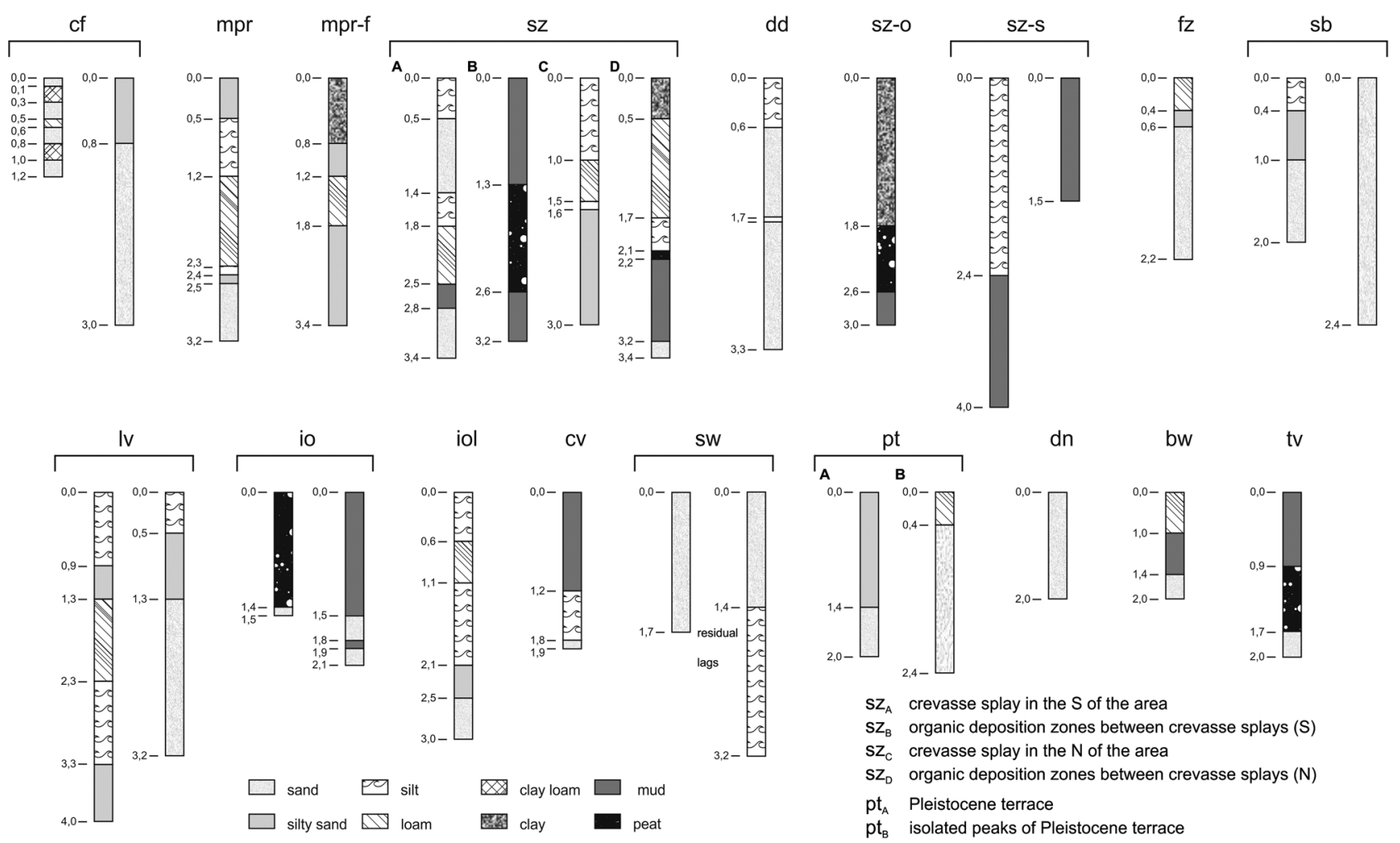

Figure 3: Lithological profiles of the identified features.

of wide strips along the channel (Figure 2). Traces of erosion caused by floodwater can be seen on its surface. Parts of this feature located deep within the floodplain are composed of medium and fine sand, usually covered by silty or clayey sand. At the boundary with the channel, this feature is composed of loams intercalated with sand layers (Figure 3).

Analysis of DEM and aerial photographs shows traces indicating that the meandering plain has been transformed by flood flows of the modern braided river. This happened before the embankments were built and is currently taking place during embankment failure. This feature covers the largest part of the valley and has the greatest lithological variability. Due to differences in morphology, two features can be distinguished: meander plains reworked by flows of the contemporary braided river (mpr) with distinct traces of meander migration and meander plains reworked by flows of the contemporary braided river (mpr-f), on which these traces have been completely removed, and the surface is flat and levelled. The mpr-f usually occurs in the direct vicinity of the contemporary or ancient river channel or near concentrated flow zones of floodwaters (fz) (Figure 2). The mpr is characterised by diverse lithological profiles, though clay-silty muds with irregular intercalations of sands and, occasionally, clays mainly occur here. Comparatively, the mpr-f is composed of clay loams, loams, clays and, occasionally, silts. Variably grained sand also occurs at the base of the mpr and mpr-f profiles (Figure 3).

In the southern part of the study area, in the "mouth" (estuary) of the Krępianka River (left tributary of the Vistula River), stagnation zones (sz) occur. These consist of large surfaces of irregular outline, with deposition of organic deposits (Figure 2). Their formation is related to blocking of water runoff by contemporary depositional zones. Organic deposits are often covered with a layer of mineral sediments (sands and loams). Such stagnation zones (sz) also include landlocked depressions on the surface of the meander plain, periodically flooded by waters of the contemporary Vistula River. They are also characterised by a specific, bipartite structure; crevasse splays occur in this area. These forms comprise a series of elongated radial bars separated by depressions. At the "mouth" of the Krępianka, the crevasse splays are composed of sands or loamy-silty muds intercalated with sands, often with the sand at the base. Depressions between them are usually filled with peats and muds, often covered by loamy-silty mud, with intercalations of sand at the base. In the northern part of the area, organic deposits of $\mathrm{sz}$ are characterised by much lower organic matter content than in the southern part. Peats occur here as individual 
intercalations. Profiles of the depressions comprise clay-loamy muds with sand at the base, and those of the splays include loams, silts and silty sands (Figure 3 ).

The deltaic deposition zone (dd) that blocks water runoff at the mouth of the Krępianka has been formed and still develops during high water of both the Vistula and Krępianka rivers. It is characterised by a smooth surface incised by fan-like, shallow and narrow depressions. It also comprises fine sands with a thickness exceeding $3 \mathrm{~m}$, covered by a mud layer of the contemporary braided river, developed as silt (Figure 3).

Buried oxbow lakes (sz-0) occur in the southern part of the study area, on the left bank of the Vistula River (Figure 2). They form distinct depressions on the surface of the reworked meander plain. They are only partly reworked (covered by younger deposits). The sz-o profile is composed of peats and muds, overlain by clay-loamy muds with thicknesses ranging from 0.5 to $1.5 \mathrm{~m}$ (Figure 3).

Elongated depressions - escarpment foot back swamps (sz-s) - occur at the boundary between the valley and the plateau in the northern part of the study area, on the left bank of the Vistula River. Sets of these depressions are distributed parallel to the plateau margin (Figure 2). The zones of escarpment foot back swamps are places of the smallest aggradation of contemporary floodwater deposits, resulting in accumulation of the finest material. As a result, these zones are characterised by lower elevations than the surrounding features. This favours the development of hydrogenic habitats. They are supplied both from floodwater and groundwater flowing from higher levels. Their profile is composed of clay-silty muds, occasionally interbedded (or covered) with sands. The thickness of muds is usually slightly below $1.0 \mathrm{~m}$ (Figure 3).

Concentrated flow zones of floodwaters ( $\mathrm{fz}$ ) can be recognised on the floodplain surface. They are developed as elongated forms characterised by surface relief parallel to their elongation. Their profiles show grain size coarsening with depth. On the surface, the deposits include loams and silty loams or silts, passing downwards into fine sands interbedded with silt and fine and medium sands (Figure 3).

Sandy bars (sb) were distinguished within the fz or in their direct vicinity in the central and northern parts of the analysed stretch of the Vistula River. They form lenticular structures parallel to the channels of concentrated flow (Figure 2). The sb profile comprises fine and medium sands with a thickness exceeding $2 \mathrm{~m}$, sometimes covered by loamy-silty muds or interbedded with silty sands (Figure 3 ).

The presence of levee deposition zones (lv) was noted in the direct vicinity of the Vistula River channel, $\mathrm{fz}$ and oxbow lakes. Their profile comprises loamy-silty muds interbedded with sandy deposits. Profiles composed of sands usually covered with silt were also observed (Figure 3).

Oxbow lakes occur on the surface of the meander plain, often with traces of reworking by contemporary floodwater. Presently, they are filled with organic (ol) and mineral deposits (iol). Oxbow lakes are variably developed in the northern and southern zones of the analysed stretch of the Vistula River. In the southern zone, ol are largely reworked into small and narrow forms. In turn, in the northern part of the area, they occur mainly in a zone adjacent to the margin of the upper terrace as well-developed depressions reflecting the ancient shape of the channel, in which sedimentation of lake and bog deposits took place (Figure 2). Their profile is composed of peats and muds with fine and medium sands at the base. In turn, a series of iol forms, also in the northern part of the floodplain in the analysed stretch, are composed of silts, silty sands and sands occasionally interbedded with loam (Figure 3). They attain characteristic shapes of ancient meanders with traces of floodwater flows.

In places where floodwaters entered the meander plain forming sz, small elongated depressions - crevasses $(\mathrm{cv})$ - were formed. Their profile comprises clay muds underlain with silt. Fine sands occur at the base of the profile (Figure 3).

Slope wash zones (sw) represented by small fans were noted only in the northern part of the study stretch, at the base of the plateau slope (Figure 2). They are composed of fine sands with the debris of Cretaceous limestones, $1.4-1.9 \mathrm{~m}$ in thickness. Below, there are loamy-silty muds of the meandering river, or muds and clays of ancient back swamps formed at the foot of the escarpment. Occasionally, residual lags occur at the base of this feature. The morphologically lower parts of sw are covered by silty muds of the contemporary braided river (Figure 3).

The Pleistocene terrace $(\mathrm{Pt})$ is also observed in the analysed stretch (Figure 2). Its character and preservation in the northern and southern parts are different. In the southern part, its fragments occur as isolated elevations - outliers or narrow sandy strips adjacent to the escarpment. In the north, this upper terrace forms a vast sandy horizon, over $2 \mathrm{~km}$ wide. The Pt profile comprises fine, medium, coarse and silty sands and, in some locations, silts. Locally, outliers of this terrace are characterised by the presence of loamy horizons with variable thickness. Dunes (dn) and blowouts (bw) occur on the surface of Pt (Figure 2). The features of dn are 

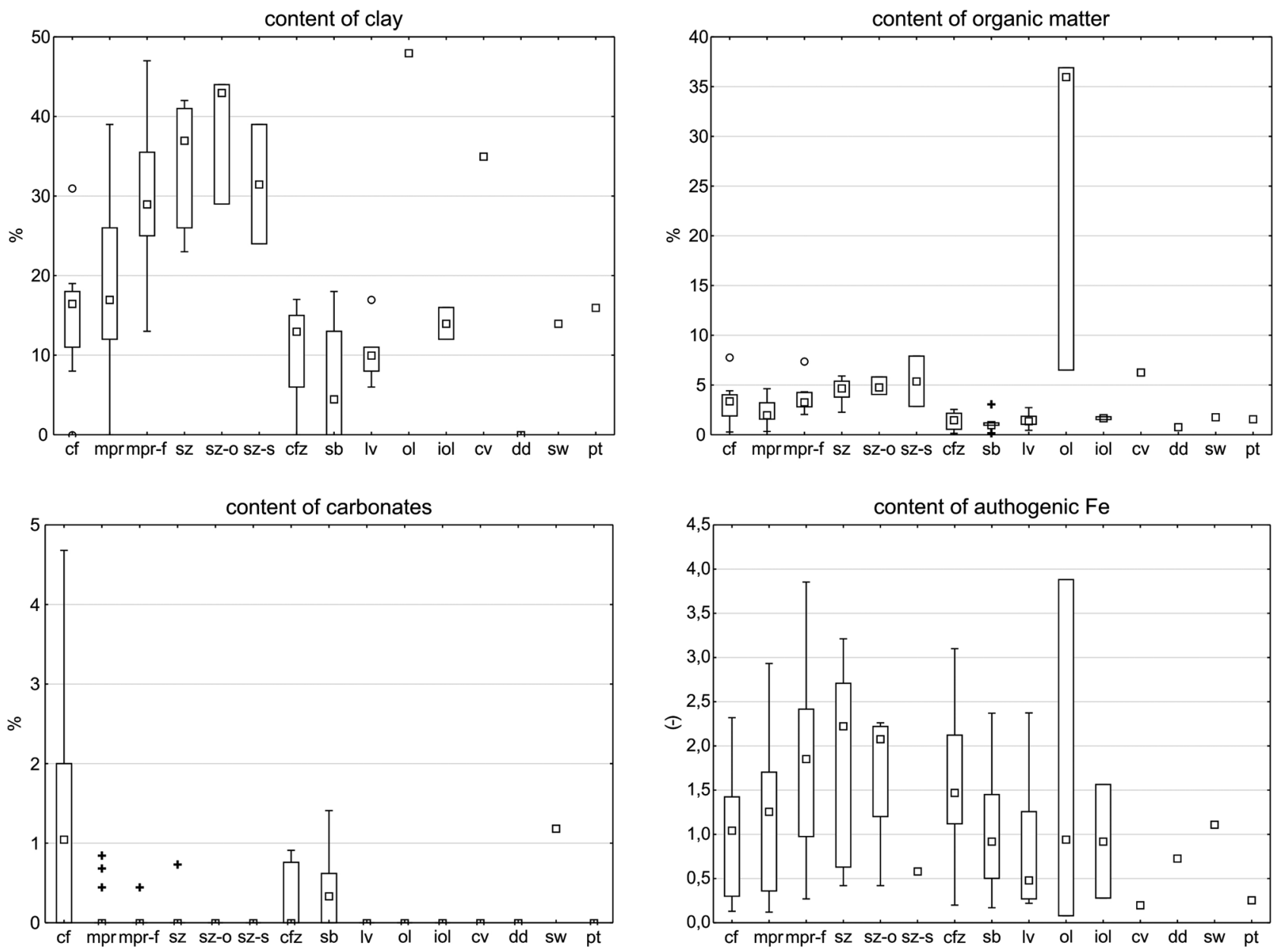

a median $\square 25 \%-75 \%$ I min-max o outliers + extreme

Figure 4: Clay fraction, organic matter, iron oxides and hydroxides and calcium carbonate contents in deposits of particular features of the study area.

composed of fine and medium sand, whereas those of bw are represented by thin loamy muds (about $1 \mathrm{~m}$ ) with sands at the base (Figure 3).

In the mouth zone of the Krępianka tributary valley (tv), about $400 \mathrm{~m}$ wide (Figure 2), organic deposits occur. At a depth of $0.8-1.0 \mathrm{~m}$, below a layer of silts interbedded with silty loams or sandy muds, $0.8 \mathrm{~m}$ thick peats are found. Fine sands occur at the base of the peats (Figure 3).

The individual features differ in the content of clay fraction, organic matter, carbonates and iron oxides and hydroxides (Figure 4). The highest contents of the clay fraction and organic matter occur in ol, sz, sz-o, sz-s and cv deposits and slightly lower in mpr-f deposits. The average values in the deposits of these features vary from 31 to $48 \%$ for the clay fraction content and from 4 to $26 \%$ for the organic matter content (Figure 4). The lowest contents of clay fraction and organic matter were noted in dd, sb, lv, fz, sw and pt deposits. In turn, the highest variability of the content of clay fraction is observed in mpr deposits, while of organic matter in ol deposits. In all these deposits, the range of the obtained results is very wide and varies from 0 to $48 \%$ for the clay fraction content and from 0 to $37 \%$ for the organic matter content. The highest and most variable carbonate content is found in cf deposits. Moreover, carbonates occur in $\mathrm{fz}, \mathrm{sb}$ and sw deposits, as well as in single samples from mpr, mpr-f and sz. The $\mathrm{CaCO}_{3}$ content does not exceed 5\%. The highest average contents of iron oxides and hydroxides are found in sz deposits (1.92\%; Figure 4).

\subsection{Heavy metal content in the sediments of individual floodplain features}

The trace element contents in deposits of individual floodplain features in the study stretch of the Vistula River display 

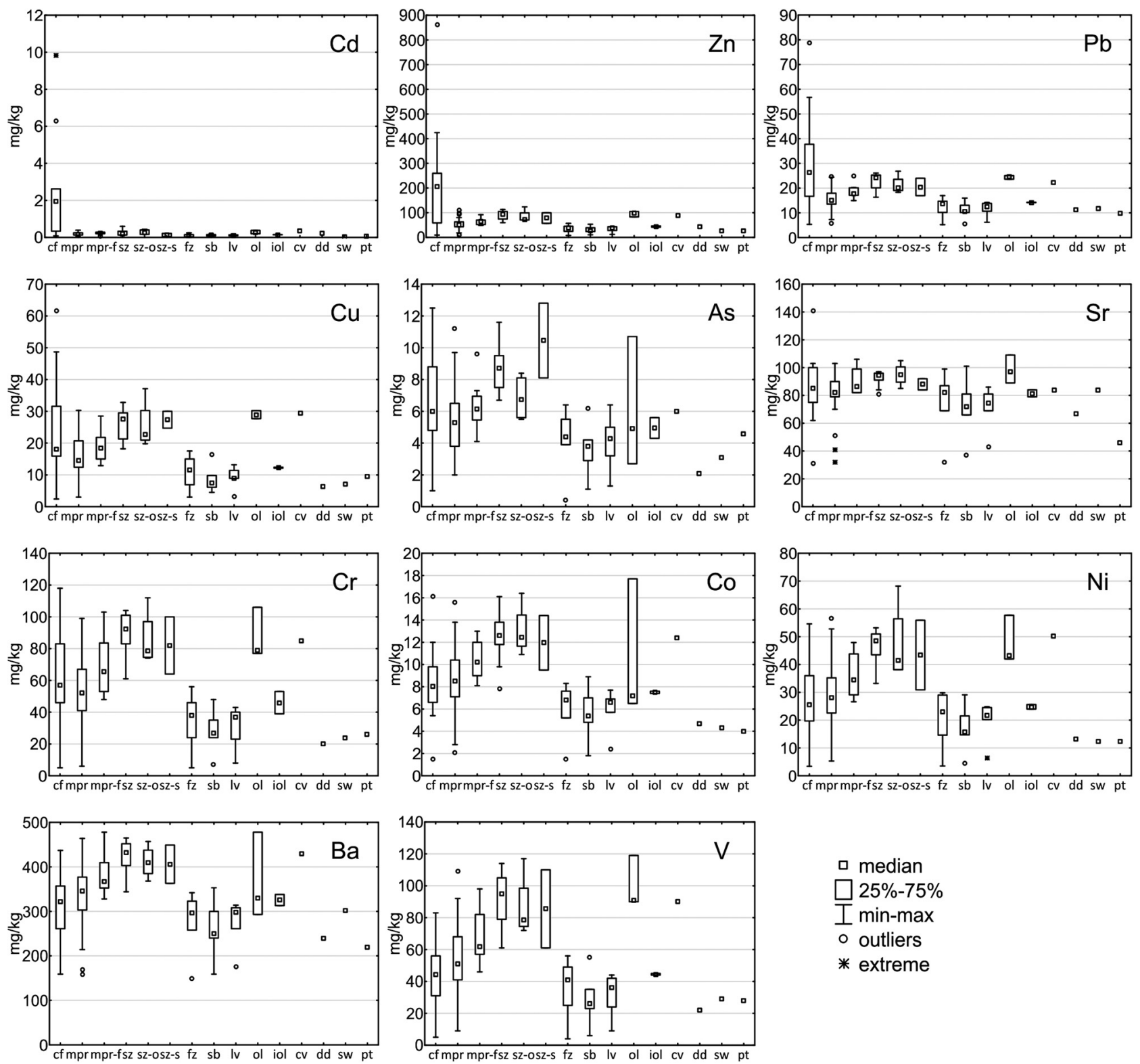

Figure 5: Heavy metal concentrations in deposits of particular features in the analysed stretch of the Vistula River.

considerable variability (Figure 5). In the $1.0 \mathrm{~mm}$ fraction (the particle-size class), $\mathrm{Cd}, \mathrm{Zn}$ and $\mathrm{Pb}$ have the highest and most variable concentrations in cf deposits. This is the most evident in the case of $\mathrm{Cd}$ (average concentration $2.67 \mathrm{ppm}$ ). The highest concentrations of the remaining elements $(\mathrm{Cu}$, $\mathrm{Ni}, \mathrm{Co}, \mathrm{As}, \mathrm{Sr}, \mathrm{V}, \mathrm{Cr}$ and $\mathrm{Ba}$ ) occur in ol, cv, sz, sz-o and sz-s deposits, and the lowest in sb, dd, sw, pt, lv and fz deposits. The greatest variability of all heavy metal contents is observed in cf and mpr deposits (Figure 5).

The concentrations of trace elements are higher in the $0.063 \mathrm{~mm}$ fraction than in the particle-size class $1.0 \mathrm{~mm}$, with smaller differences between deposits composing individual features (Figure 6). The highest concentrations of $\mathrm{Pb}, \mathrm{Zn}$ and
Cd were noted in cf and dd; Co and As in cf, sz-s and dd; $\mathrm{Cu}$ and $\mathrm{Cr}$ in cf, sz, sz-o, sz-s and ol; V in sz, sz-o, sz-s and ol; and $\mathrm{Ni}$ and $\mathrm{Ba}$ in sz, sz-o and sz-s. The lowest Sr contents were observed in cf deposits (Figure 6). For the $0.063 \mathrm{~mm}$ fraction, the lowest concentrations were observed in deposits of sw $(\mathrm{Cu}, \mathrm{Pb}, \mathrm{Zn}, \mathrm{Ni}, \mathrm{Co}, \mathrm{As}, \mathrm{V}$ and $\mathrm{Cr})$, ol (Co, As) and pt (Ni and $\mathrm{Co}$ ) (Figure 6).

\subsection{Statistical analysis}

According to PCA, the distribution of $\mathrm{Cd}, \mathrm{Zn}$ and $\mathrm{Pb}$ is influenced mostly by the carbonate content. In contrast, 

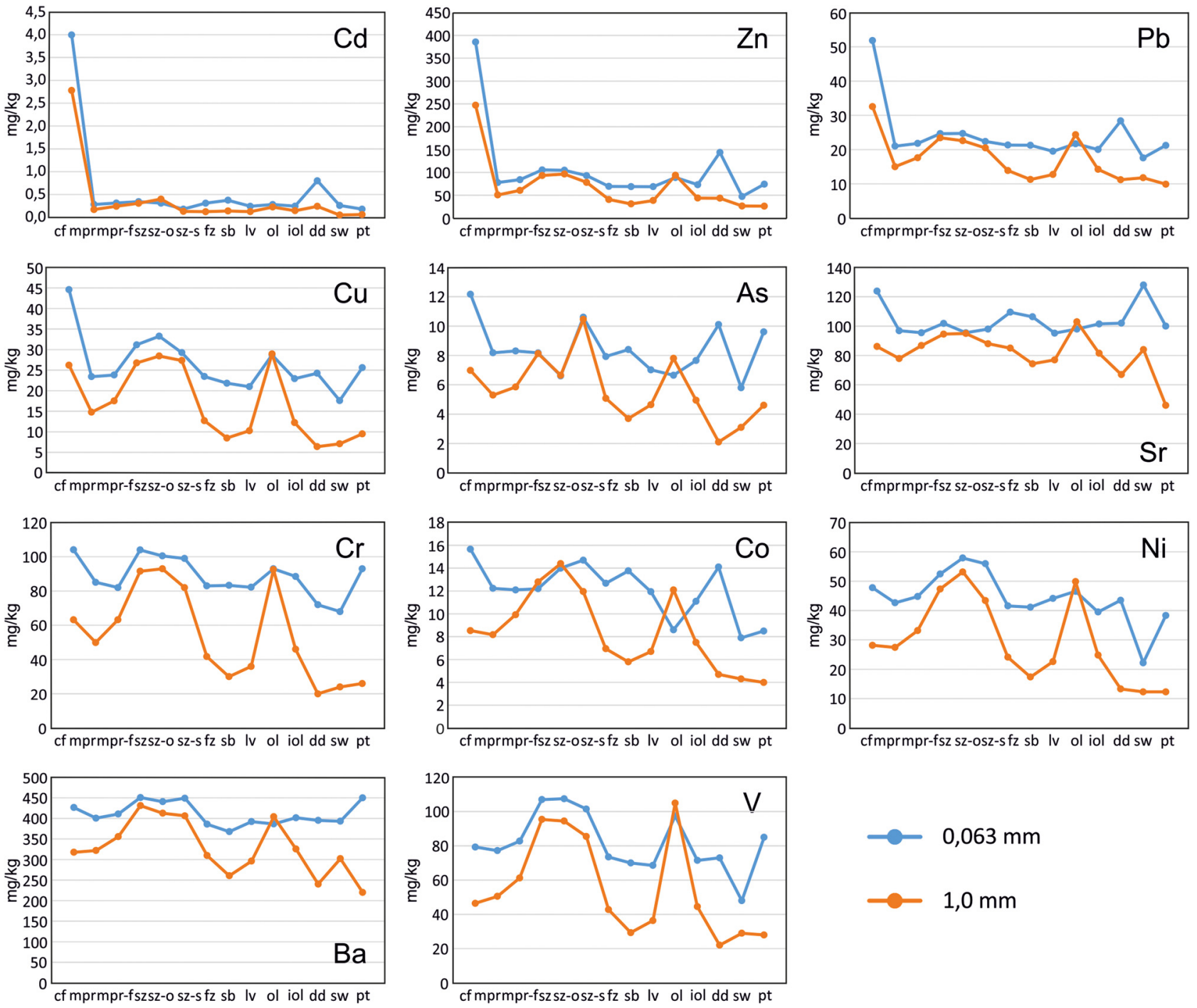

Figure 6: Comparison of the heavy metal concentrations in the 0.063 and $1.0 \mathrm{~mm}$ fractions of deposits studied.

the distribution of $\mathrm{Cr}, \mathrm{Sr}, \mathrm{Cu}$ and As depends on the organic matter content, while the distribution of $\mathrm{Ba}$, Co, $\mathrm{V}$ and $\mathrm{Ni}$ is dependent on the clay fraction content (Figure 7). This is confirmed by regression analysis. An exception is the $\mathrm{Pb}$ concentration that depends on the organic matter content more strongly than on the carbonate content, according to the formula:

$$
\mathrm{Pb}=3.282 \times \mathrm{OM}+6.610 \times \mathrm{CaCO}_{3}+6.719,
$$

where $\mathrm{Pb}$ is the $\mathrm{Pb}$ concentration in the deposit $(\mathrm{mg} / \mathrm{kg})$, $\mathrm{OM}$ is the organic matter content $(\%)$ and $\mathrm{CaCO}_{3}$ is the carbonate content (\%); the standardised coefficient between $\mathrm{Pb}$ concentration in the deposit and organic matter content is 0.584 , and the standardised coefficient between $\mathrm{Pb}$ concentration in the deposit and carbonate content is 0.508 .
Cr concentration depends more strongly on the clay fraction content than on the organic matter content, according to the formula:

$$
\mathrm{Cr}=1.188 \times \mathrm{CLAY}+5.976 \times \mathrm{OM}+12.444
$$

where $\mathrm{Cr}$ is the $\mathrm{Cr}$ concentration in the deposit $(\mathrm{mg} / \mathrm{kg})$, CLAY is the clay content (\%) and OM is the organic matter content (\%); the standardised regression coefficient between $\mathrm{Cr}$ concentration in the deposit and clay content is 0.531, and the standardised regression coefficient between $\mathrm{Cr}$ concentration in the deposit and organic matter content is 0.386 .

DCA shows that the heavy metal concentrations in the deposits vary among individual floodplain features (Figure 8). This is best seen in the case of contemporary floodplain (cf) deposits. Such forms as deltaic deposition 


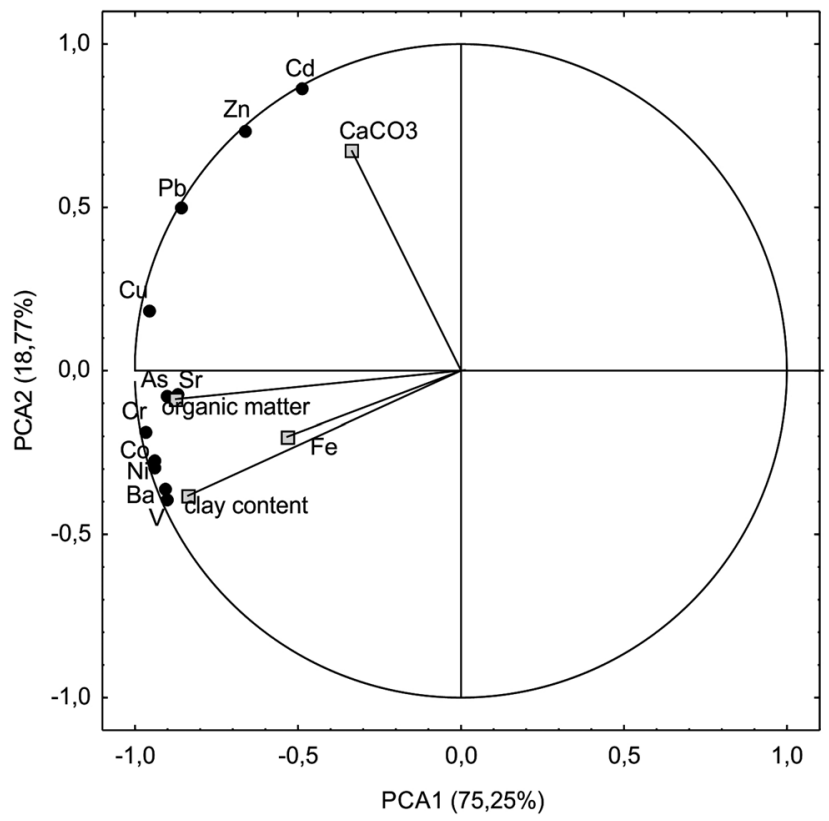

Figure 7: PCA for heavy metals in the deposits studied.

zones (dd), Pleistocene terrace (pt), slope wash zones (sw) and oxbow lakes (ol) are less clearly distinguished. The trace element contents in stagnation zones of floodwaters (sz), oxbow lakes buried under floodplain or organic deposits (sz-o), escarpment foot back swamps (sz-s) and crevasses (cv), as well as concentrated flow zones of floodwaters (fz), sandy bars (sb) and levee deposition zones (lv) show similarities. In turn, the most variable heavy metal concentrations are found in the
Table 1: Results of ANOVA analysis and Kruskal-Wallis statistics

\begin{tabular}{lcclll}
\hline Heavy metal & \multicolumn{2}{l}{ ANOVA test } & & \multicolumn{2}{c}{ Kruskal-Wallis test } \\
\cline { 2 - 3 } \cline { 6 - 6 } & $\boldsymbol{F}(\mathbf{3 . 7 7})$ & $\boldsymbol{p}$ & & KW-H (3.81) & $\boldsymbol{p}$ \\
\hline $\mathrm{Cu}$ & 18.3673 & 0.0000 & & 41.7947 & 0.0000 \\
$\mathrm{~Pb}$ & 15.6895 & 0.0000 & & 42.1201 & 0.0000 \\
$\mathrm{Zn}$ & 14.7354 & 0.0000 & & 44.1310 & 0.0000 \\
$\mathrm{Ni}$ & 22.2030 & 0.0000 & & 39.2931 & 0.0000 \\
$\mathrm{Co}$ & 11.0608 & 0.0000 & & 25.5777 & 0.0000 \\
$\mathrm{As}$ & 15.2596 & 0.0000 & & 32.5123 & 0.0000 \\
$\mathrm{Sr}$ & 4.5257 & 0.0056 & & 17.7873 & 0.0005 \\
$\mathrm{Cd}$ & 15.8970 & 0.0000 & & 26.2270 & 0.0000 \\
$\mathrm{~V}$ & 29.8521 & 0.0000 & & 43.9452 & 0.0000 \\
$\mathrm{Cr}$ & 23.9058 & 0.0000 & & 41.7917 & 0.0000 \\
$\mathrm{Ba}$ & 15.7257 & 0.0000 & & 34.1266 & 0.0000 \\
\hline
\end{tabular}

deposits of meander plain reworked by flows of contemporary braided river (mpr) (Figure 8).

ANOVAs for deposits of the contemporary floodplain (cf), meander plain reworked by flows of the contemporary braided river (mpr), stagnation zones of floodwaters (sz) and concentrated flow zones of floodwaters (fz) show differences in the contents of the analysed heavy metals (Table 1).

\section{Discussion}

The processes of evolution of fluvial systems, influencing the floodplain morphology $[50,51]$, depend on many

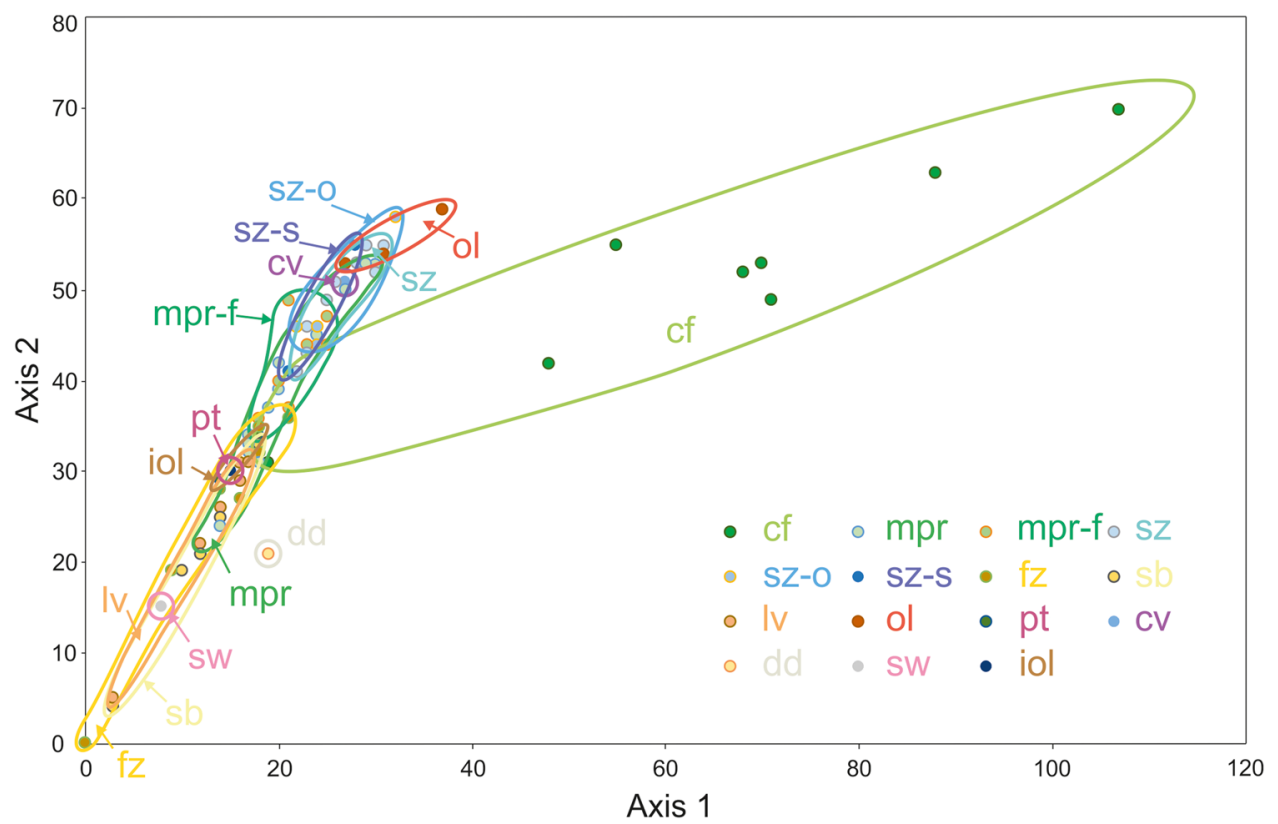

Figure 8: DCA for heavy metals in the deposits studied. 
factors, such as tectonic processes [52,53], climate change [41,54] and changes in the settings of the catchment area caused by, e.g., human industrial activity (e.g. [42,51,55-58]). Such phenomena also influenced the relief of the analysed stretch of the Vistula River valley, as well as caused the development of a specific feature pattern and the lithology and chemical composition of deposits of these forms. Our results show that the distribution of heavy metals in these forms is strictly linked with the pattern and deposit composition of these features. In general, heavy metal concentrations measured by us in the alluvia of the Vistula River in the analysed stretch are higher than those presented in the Geoenvironmental Map of Poland $[59,60]$ and the Geochemical Atlas of Poland [61,62], but lower than the contents found in floodplain deposits of polluted European rivers, e.g. the Rhine [8], Dill [4], Seine [23], Odiel [6] and Ohře [63].

Differences in the concentrations of trace elements have so far been determined in deposits of many river valleys: Lahn [21,35], Bystrzyca [64,65], Warta near Poznań [66] and Middle Odra valley [22]. However, these studies consider only the distance from the sampling sites to the river channel without the subdivision of the valley into features. Our investigations have shown that the distribution of trace elements in the alluvia of the Vistula River near Kępa Gostecka differs among individual features (Figure 5). The presented relationships between the concentration of heavy metals in deposits and the pattern of floodplain features are in accordance with the regularities observed in other parts of the Vistula River valley - within a stretch formed in nonrocky deposits [14] and in a stretch located upstream the study area, i.e. near Solec nad Wisłą [49]. Spatial variability of heavy metal concentration was earlier observed also in the Biała Przemsza and Sztoła river valleys [24], but those studies focused on deposits of the channel and the adjacent contemporary floodplain. Such analyses were also carried out in the Odra valley and the Upper Vistula valley near Oświęcim [67]. However, the tested stretches have been channelled there, which makes them difficult to compare with the Vistula in our research area.

The distance from the channel is included in most analyses of heavy metal content in alluvial deposits, but the obtained relationships are not unequivocal and repeatable. Some researchers have observed the highest concentrations in the direct neighbourhood of the channel $[21,22,35]$, which was attributed to the fact that the elements were supplied to the floodplain located at some distance from the channel only during extensive floods. In contrast, other studies have noted the increase in heavy metal concentration with increasing distance from the channel [13]. This was linked with the increasing content of the finest fraction in the deposits, resulting from the smaller flow dynamics of floodwater reaching the valley margin. The discrepancy of the obtained results may also result from analysing different fractions $-0.063 \mathrm{~mm}$ by Martin [21,35] and Ciszewski [22] and $1.0 \mathrm{~mm}$ by Wyżga and Ciszewski [13]. In the present study, we also show differences in the trace element content in transverse cross-sections, different for the individual fractions. However, in the study site, the observed variations of heavy metal content in deposits of the $1.0 \mathrm{~mm}$ fraction correspond to the feature pattern and not to the distance from the channel. In turn, most elements $(\mathrm{Cd}, \mathrm{Zn}, \mathrm{Pb}, \mathrm{Cu}, \mathrm{As}, \mathrm{Sr}$ and to a smaller degree $\mathrm{Cr}$ ) of the $0.063 \mathrm{~mm}$ fraction show the highest concentrations in direct vicinity of the channel, i.e. in deposits of cf that developed during the greatest supply of pollutants, particularly from the mining areas of Upper Silesia. Considerably smaller concentrations were noted in the remaining deposits composing forms located much further from the channel (Figure 9). Increased supply of heavy metals in the Vistula River valley is also influenced by the mineral composition of these deposits, playing an essential role in binding trace elements. Lithology, controlled by the sedimentary conditions, particularly the contents of the clay fraction, organic matter, carbonates and free iron oxides and hydroxides $[18,68-70]$, influences the variable concentration of heavy metals in deposits of individual valley zones. The PCA performed for the deposits of the Vistula River valley near Kępa Gostecka, with the principal components corresponding to the proxies mentioned above, has shown regularities in geochemical affinity of the analysed elements. It also allowed explaining the variable concentration of these elements in deposits of various floodplain zones. Because the variable concentrations of $\mathrm{Cd}, \mathrm{Zn}$ and $\mathrm{Pb}$ are influenced mostly by the carbonate content (Figure 7), and the deposits containing $\mathrm{CaCO}_{3}$ - compared with other features - are most common in cf, these elements reach the highest concentrations in cf deposits (Figure 5). In turn, organic matter is a factor determining the variability of contents of $\mathrm{Sr}$, $\mathrm{As}, \mathrm{Cr}$ and $\mathrm{Cu}$, while the clay fraction is most important in the case of $\mathrm{V}, \mathrm{Ba}, \mathrm{Co}$ and Ni (Figure 7). The forms related to river water stagnation, which contain large amounts of organic matter, are also characterised by high clay fraction content. Therefore, elements linked with organic matter and clay fraction reach the highest concentrations (in the $1.0 \mathrm{~mm}$ fraction) in ol, sz, sz-o, 
$1,0 \mathrm{~mm}$
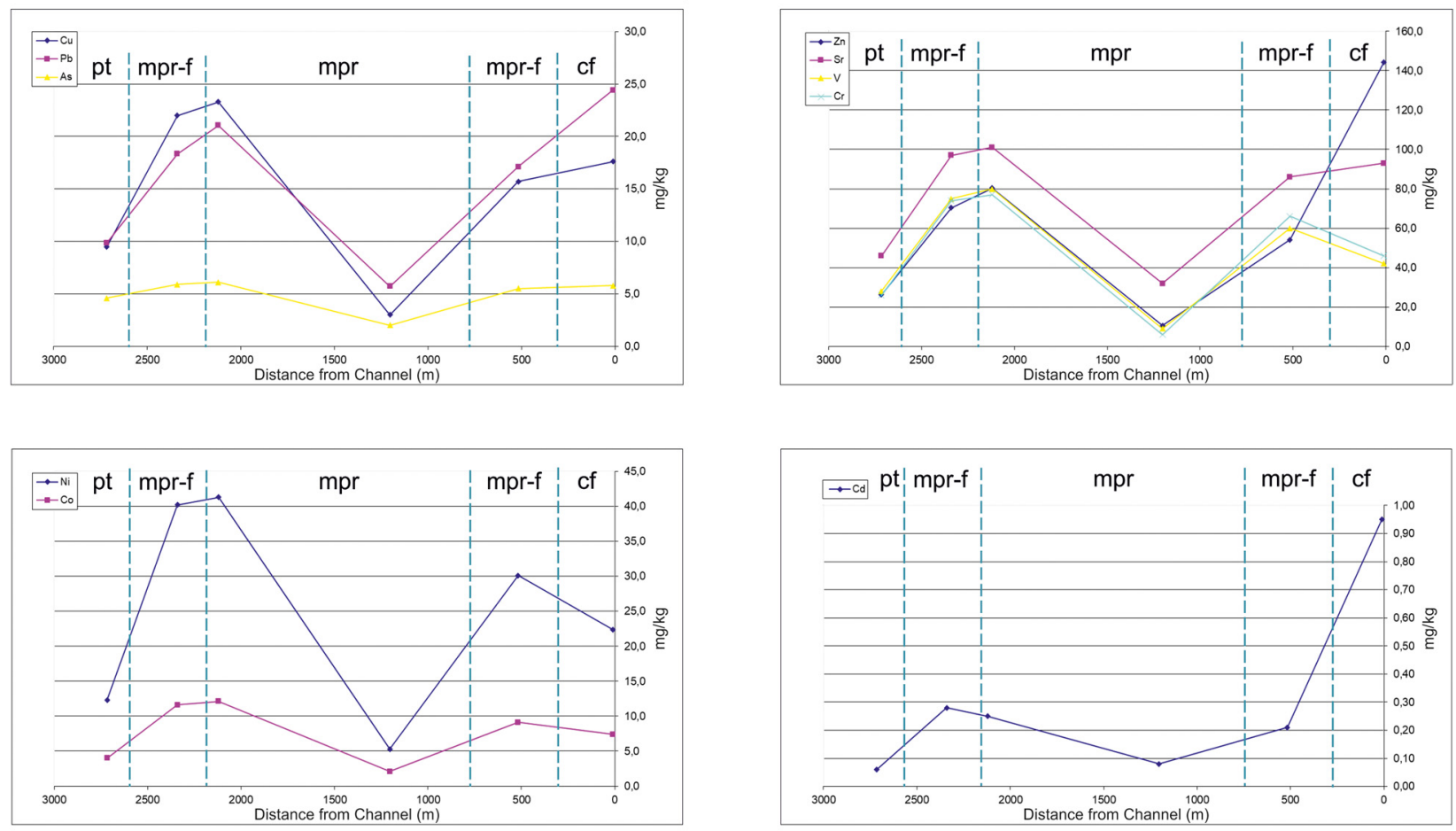

\section{$0,063 \mathrm{~mm}$}
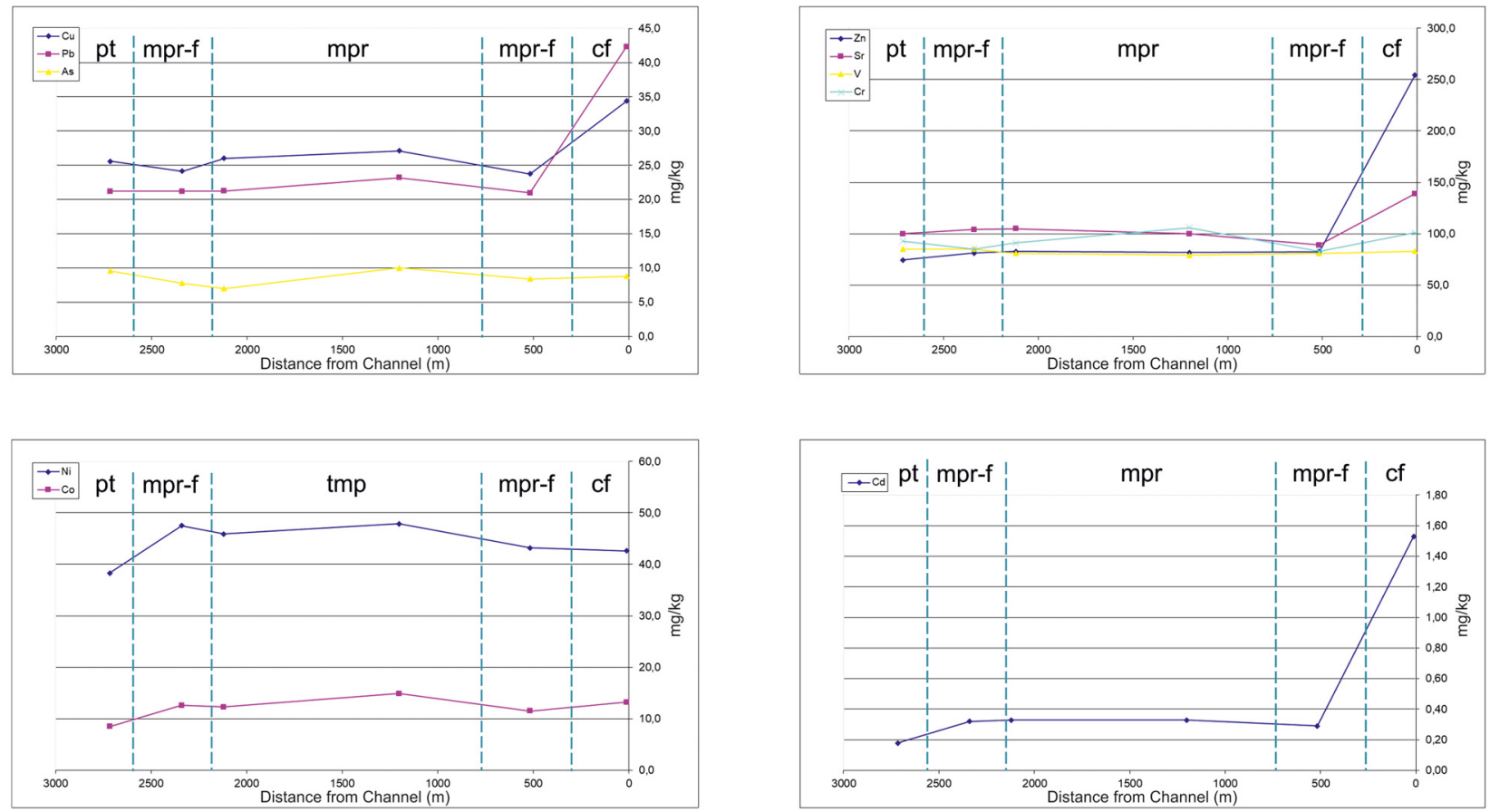

Figure 9: Heavy metal concentrations depending on the distance from the channel in the 0.063 and $1.0 \mathrm{~mm}$ fractions. See Figure 1 for the location of cross-sections.

sz-s and cv deposits. The influence of iron oxides and hydroxides on the distribution of heavy metals in the study area is not significant, as indicated by both PCA and regression analyses. This may result from the fact 
that the contents of iron compounds do not differ in the deposits of individual features (Figure 4).

In the analysed stretch of the Vistula River, the complex structure of the floodplain corresponds to the variable distribution of heavy metals in deposits of individual features. Thus, there is a relationship between the distribution of heavy metal concentration within the floodplain features and their origin. This relationship is marked more strongly in the analysis of the $1.0 \mathrm{~mm}$ fraction, although the concentrations observed in this fraction are generally lower than in the $0.063 \mathrm{~mm}$ fraction (Figure 6). This results from the fact that the finer $(0.063 \mathrm{~mm})$ of the two particle fractions is characterised by a higher content of clay fraction and organic matter $[9,71]$. Selection of the chemically most active components of the deposits causes obliteration of the impact of fluvial processes having an influence on the lithological variability of the deposits. Therefore, trace elements in the $0.063 \mathrm{~mm}$ fraction, collected from floodplain deposits, allow for the comparison of their load supplied to the river at different moments. In turn, the results obtained for the $1.0 \mathrm{~mm}$ fraction better reflect sedimentary and morphogenetic processes within the river valley.

The highest concentrations of heavy metals in the $1.0 \mathrm{~mm}$ fraction were recorded in deposits forming the surface of periodically flooded zones, characterised by quiet sedimentation: sz, sz-o, sz-s, cv and ol (Figure 5). High contents of trace elements in these zones result from the fact that these forms are filled with muds and, locally, by peats with high clay and organic matter contents (Figure 4). Stagnation of polluted waters of the Vistula River has also been observed in such zones, which, after the construction of flood embankments, reach here through embankment breakdown. The lowest concentrations of heavy metals in the $1.0 \mathrm{~mm}$ fraction were noted in deposits of zones linked with fast floodwater flows, comprising coarser deposits with low organic matter content. They include $\mathrm{fz}, \mathrm{sb}, \mathrm{lv}$ and $\mathrm{dd}$, as well as topographically upper and older features - sw and pt (Figure 5).

In turn, the most variable trace element contents (in the $1.0 \mathrm{~mm}$ fraction) were observed in mpr deposits. This variability results from the very diverse sedimentary conditions of the different lithologies composing this part of the floodplain [42,45,72]. Compared to $\mathrm{mpr}$, slightly higher concentrations of heavy metals were noted in the analysed stretch of the Vistula River in mpr-f deposits characterised by a higher content of the clay fraction and organic matter (Figure 3). This feature is usually located near the channel or near the fz.
Deposits of cf can be clearly distinguished in the heavy metal analysis (in the $1.0 \mathrm{~mm}$ fraction). The highest contents of $\mathrm{Cd}, \mathrm{Zn}$ and $\mathrm{Pb}$ and high contents of $\mathrm{Sr}, \mathrm{Ni}$, $\mathrm{Cu}$ and $\mathrm{Cr}$ (Figure 5) are due to the presence of clay fraction, organic matter and calcium carbonate in these deposits. Their presence results from the occurrence of stagnation periods of floodwater in the zone between the embankments, during which deposition of fine sediments from suspension, additionally enriched in calcium carbonate, takes place. The occurrence of high concentrations of $\mathrm{Cd}, \mathrm{Zn}$ and $\mathrm{Pb}$ in cf deposits is commonly observed in river valleys located in industrial areas [73,74]. High (exceeding background values) concentrations of these elements in deposits of the contemporary floodplain in the direct vicinity of the channel were earlier indicated, e.g. in the Bystrzyca [64], Lahn [21,35] and Middle Odra valleys [22].

The highest concentrations of most heavy metals in the $0.063 \mathrm{~mm}$ fraction were found in $\mathrm{cf}(\mathrm{Cd}, \mathrm{Zn}, \mathrm{Pb}, \mathrm{Cu}$, $\mathrm{As}, \mathrm{Sr}, \mathrm{Co}$ and $\mathrm{Cr}$ ) and dd deposits $(\mathrm{Cd}, \mathrm{Zn}, \mathrm{Pb}, \mathrm{Cu}, \mathrm{As}$ and Co). This is because a greater amount of polluted material was supplied to the area located closest to the contemporary channel. High concentrations of $\mathrm{Cu}, \mathrm{Ni}, \mathrm{V}$, $\mathrm{Cr}$ and $\mathrm{Ba}$ in the $0.063 \mathrm{~mm}$ fraction were also recorded in deposits from features characterised by calm sedimentation, flooded periodically during contemporary (prior to embankment construction) floods (sz, sz-osz-s and in the case of $\mathrm{Cu}, \mathrm{V}$ and $\mathrm{Cr}-\mathrm{ol}$ ). In turn, the lowest concentrations of most of the analysed trace elements in the $0.063 \mathrm{~mm}$ fraction were observed in the oldest features: sw, ol and pt (Figure 6), developed before the period of the most intense anthropopression and pollutant supply.

More considerable differences in the heavy metal content in the $1.0 \mathrm{~mm}$ fraction than in the $0.063 \mathrm{~mm}$ fraction indicate that analyses performed for this fraction may be used as proxies of morphogenetic processes in floodplains of contemporary rivers.

\section{Conclusions}

- The patterns of features and their lithologies in the analysed stretch of the Vistula valley are strictly related to the valley morphogenesis.

- The variable concentration of trace elements in the surface deposits is linked with the specific morphodynamics of this valley stretch.

- This variability results from different sedimentary conditions of the floodplain deposits and the possibility of mobilising the earlier deposited bedload by floodwater. 
- In the studies of content of heavy metals, the relationship between fluvial processes and their concentration is better reflected in the $1.0 \mathrm{~mm}$ fraction than in the $0.063 \mathrm{~mm}$ fraction.

Acknowledgments: This study was financed by research grant no. 012/05/B/ST10/00931 of the National Science Centre (Poland) to E. Falkowska. The authors thank the reviewers and editor for their valuable comments that helped improve the manuscript.

\section{References}

[1] Miller JR, Orbock Miller SM. Contaminated rivers: a geomorphological-geochemical approach to site assessment and remediation. Dordrecht: Springer; 2007.

[2] Plak A, Zgłobicki W, Lata L, Telecka M. Formy biodostępne Cd, $\mathrm{Cu}, \mathrm{Pb}, \mathrm{Zn}$ w osadach den dolin zachodniej części Wyżyny Lubelskiej [Bio-available forms of $\mathrm{Cd}, \mathrm{Cu}, \mathrm{Pb}$ and $\mathrm{Zn}$ in the sediments of valley bottoms in the western part of the Lublin Upland]. Landform Anal. 2014;24:65-71 (in Polish with English summary).

[3] Helios-Rybicka E. Impact of mining and metallurgical industries on the environment in Poland. Appl Geochem. 1996;11:3-9.

[4] Martin CW. Trace metal storage in recent floodplain sediments along the Dill River, Central Germany. Geomorphology. 2015;235:52-62.

[5] Leenaers H, Schouten CJ, Rang MC. Variability of the metal content of flood deposits. Environ Geol Water Sci. 1998;11:95-106.

[6] Santos Bermejo JC, Beltran R, Gomez Ariza JL. Spatial variations of heavy metals contamination in sediments from Odiel river (Southwest Spain). Environ Int. 2003;29:69-77.

[7] Förstner U, Wittmann GTW. Metal pollution in the aquatic environment. Berlin, Heidelberg, New York: SpringerVerlag; 1983.

[8] Martin CW. Heavy metal storage in near channel sediments of the Lahn River, Germany. Geomorphology. 2004;61:275-85.

[9] Miller JR. The role of fluvial geomorphic processes in the dispersal of heavy metals from mine sites. J Geochem Explor. 1997;58:101-18.

[10] Lecce SA, Pavlowsky RT. Floodplain storage of sediment contaminated by mercury and copper from historic gold mining at Gold Hill, North Carolina, USA. Geomorphology. 2014;206:122-32.

[11] Guéguen C, Dominik J. Partitioning of trace metals between particulate, colloidal and truly dissolved fractions in a polluted river: the Upper Vistula River (Poland). Appl Geochem. 2003;18:457-70.

[12] Falkowska E. Związek akumulacji metali ciężkich w osadach facji powodziowych z morfologią doliny Wisty na odcinku od Annopola do Gołębia [Relationship between the heavy metal accumulation in flood deposits and the morphology of the
Vistula River Valley between Annopol and Gotąb]. Prz Geol. 2005;53:681-6 (in Polish with English summary).

[13] Wyżga B, Ciszewski D. Hydraulic controls on the entrapment of heavy metal-polluted sediments on a floodplain of variable width, the upper Vistula River, southern Poland. Geomorphology. 2010;117:272-86.

[14] Falkowska E, Falkowski T. Trace metals distribution pattern in floodplain sediments of a lowland river in relations to contemporary valley bottom morphodynamics. Earth Surf Proc Land. 2015;40:876-87.

[15] Horowitz AJ. A Primer on Sediment-Trace Element Chemistry. Michigan: Lewis; 1991. p. 1-134.

[16] Miller JR, Lechler PJ, Desilets M. The role of geomorphic processes in the transport and fate of mercury within the Carson River Basin, West-Central Nevada. Environ Geol. 1998;33:249-62.

[17] Walling D, Owens P, Carter J, Leeks G, Lewis S, Meharg AA, et al. Storage of sediment-associated nutrients and contaminants in river channel and floodplain systems. Appl Geochem. 2003;18:195-220.

[18] Ciszewski D, Malik I, Wardas M. Uwarunkowania geomorfologiczne migracji metali ciężkich w osadach fluwialnych: dolina Małej Panwi [Geomorphological influences on heavy metal migration in fluvial deposits: the Mała Panew River valley (Southern Poland)]. Prz Geol. 2004;52: 163-74 (in Polish with English summary).

[19] Galán E, Fernandez-Caliani JC, Gonzales I, Aparicio P, Romero A. Influence of geological setting on geochemical baselines of trace elements in soils. Application to soils of South-West Spain. J Geochem Explor. 2008;98:89-106.

[20] Conde Bueno P, Bellido E, Martín Rubí JA, Jiménez Ballesta R. Concentration and spatial variability of mercury and other heavy metals in surface soil samples of periurban waste mine tailing along a transect in the Almadén mining district (Spain). Environ Geol. 2009;56:815-24.

[21] Martin CW. Heavy metal concentration in floodplain surface soils, Laher River, Germany. Environ Geol. 1997;30:119-25.

[22] Ciszewski D. Heavy metals in vertical profiles of the middle Odra river overbank sediments: evidence for pollution changes. Water Air Soil Pollut. 2003;143:81-98.

[23] Grosbois C, Meybeck M, Horowitz A, Ficht A. The spatial and temporal trends of $\mathrm{Cd}, \mathrm{Cu}, \mathrm{Hg}, \mathrm{Pb}$ and $\mathrm{Zn}$ in Seine River floodplain deposits (1994-2000). Sci Total Environ. 2006;356:22-37.

[24] Ciszewski D. Channel processes as a factor controlling accumulation of heavy metals in river bottom sediments: consequences for pollution monitoring (Upper Silesia, Poland). Environ Geol. 1998;36:45-54.

[25] Ciszewski D. Flood-related changes in heavy metal concentrations within sediments of the Biała Przemsza River. Geomorphology. 2001;40:205-18.

[26] Förstner U, Müller G. Heavy metal accumulation in river sediments: a response to environmental pollution. Geoforum. 1973;14:53-61.

[27] Förstner U, Müller G. Concentrations of heavy metals and polycyclic aromatic hydrocarbons in river sediments: geochemical background, man's influence and environmental impact. GeoJournal. 1981;5:417-32.

[28] Brügmann L. Metals in sediments and suspended matter of the River Elbe. Sci Total Environ. 1995;159:53-65. 
[29] Boszke L, Sobczyński T, Głosińska G, Kowalski A, Siepak J. Distribution of mercury and other heavy metals in bottom sediments of the middle Odra River (Germany/Poland). Pol J Environ Stud. 2004;13:495-502.

[30] Pillay S, Naidoo K, Bissessur A, Agjee N, Pillay K, Purves B, et al. Sand mining impacts on heavy metal concentrations in two important river systems of northern Kwazulu-Natal, South Africa. J Hum Ecol. 2014;47:155-62.

[31] Valskys V, Valskienė R, Ignatavičius G. Analysis and assessment of heavy metals concentrations in Nemunas river bottom sediments at Alytus city territory. J Environ Eng Landsc. 2015;23:147-54.

[32] Ciszewski D, Grygar TM. A review of flood-related storage and remobilization of heavy metal pollutants in river system. Water Air Soil Pollut. 2016;227:239.

[33] Bojakowska I, Sokołowska G, Gliwicz T. Heavy metals in recent alluvium of the Odra River. Geol Q. 1997;41:395-404.

[34] Macklin MG, Dowsett R. The chemical and physical speciation of trace metals in fine-grained overbank flood sediments in the Tyne Basin, North-East England. Catena. 1989;16:135-51.

[35] Martin CW. Heavy metal trends in floodplain sediments and valley fill, River Lahn, Germany. Catena. 2000;39:53-68.

[36] Pożaryski W. Osady rzeczne w przełomie Wisły przez wyżyny potudniowe [River sediments in the Vistula Gap across the southern uplands]. Warszawa: Państwowy Instytut Geologiczny; 1955 (in Polish).

[37] Kondracki J. Geografia regionalna Polski [Regional geography of Poland]. Warszawa: PWN; 2001 (in Polish).

[38] Pożaryski W. Jura i kreda między Radomiem, Zawichostem i Kraśnikiem [Jurassic and Cretaceous between Radom Zawichost and Kraśnik (Central Poland)]. Biuletyn Państwowego Instytutu Geologicznego. 1948;46:5-141 (in Polish).

[39] Żarski M. Szczegółowa mapa geologiczna Polski w skali 1:50,000, arkusz Putawy [Detailed Geological Map of Poland (1:50,000), Puławy sheet]. Warsaw, Poland: Polish Geological Institute; 1998 (in Polish).

[40] Żarski M. Objaśnienia do szczegótowej mapy geologicznej Polski w skali 1:50 000, arkusz Puławy [Explanations for the Detailed Geological Map of Poland (1:50,000), Puławy sheet.]. Warsaw: Polish Geological Institute; 1998 (in Polish).

[41] Starkel L. Historia doliny Wisty od ostatniego zlodowacenia do dziś [Evolution of the Vistula River valley since the last glaciation till present]. Warszawa: Polish Academy of Sciences, Institute of Geography and Spatial Organization; 2001 (in Polish with English summary).

[42] Falkowski E. History and prognosis for the development of bed configurations of selected sections of Polish Lowland rivers. Biuletyn Geologiczny. 1971;12:5-121 (in Polish with English summary).

[43] Pożaryski W, Maruszczak H, Lindner L. Młodoczwartorzędowe tarasy akumulacyjne i osady deluwialne w dolinie środkowej Wisty [Late Quaternary river terraces and deluvial deposits in the Middle Vistula valley (Central Poland)]. Prz Geol. 1999;47:808-12.

[44] Ralska-Jasiewiczowa M. Impact of prehistoric man on natural vegetation recorded in pollen diagrams from different regions of Poland. Folia Quaternaria. 1977;49:75-91.
[45] Falkowski E. Ewolucja holoceńskiej Wisły na odcinku Zawichost - Solec I inżyniersko-geologiczna prognoza jej dalszego rozwoju [Evolution of the Holocene Vistula from Zawichost to Solec with an engineering-geological prediction of further development]. Biuletyn Instytutu Geologicznego. 1967;198:57-131 (in Polish).

[46] Starkel L. The reflection of hydrologic changes in fluvial environment of the temperate zone during the last 15,000 years. In: Gregory KJ, editor. Background to Paleohydrology: a perspective. Chichester, New York: Wiley; 1983. p. 213-34.

[47] Falkowski T. Naturalne czynniki stabilizujące wybrane odcinki strefy korytowej Wisty Środkowej [Factors of natural stability of the Middle Vistula River channel zones]. Warszawa: Wydawnictwo SGGW; 2006 (in Polish with English summary).

[48] Myślińska E. Laboratoryjne badania gruntów i gleb [Laboratory Soil Investigations]. Warszawa: Wydawnictwa Uniwersytetu Warszawskiego; 2010 (in Polish).

[49] Falkowska E, Falkowski T, Tatur A, Katmykow-Piwińska A. Floodplain morphodynamics and dis-tribution of trace elements in overbank deposits, Vistula River Valley Gorge near Solec nad Wisłą, Poland. Acta Geol Pol. 2016;66:541-59.

[50] Miall AD. The geology of fluvial deposits. Sedimentary facies, basin analysis and petroleum geology. Berlin: Springer Verlag; 1996.

[51] Vanderberghe J. The relation between climate and river processes, landforms and deposits during the quaternary. Quatern Int. 2002;91:17-23.

[52] Ouchi S. Response of alluvial rivers to slow active tectonic movement. Geol Soc Am Bull. 1985;96:504-15.

[53] Silva CL, Morales N, Crósta AP, Costa SS, Jiménez-Rueda JR. Analysis of tectonic-controlled fluvial morphology and sedimentary processes of the western Amazon Basin: an approach using satellite images and digital elevation model. An Acad Bras Ciênc. 2007;79:693-711.

[54] Kalicki T. Zapis zmian klimatu oraz działalności człowieka i ich rola w holoceńskiej ewolucji dolin środkowoeuropejskich [Reflection of climatic changes and human activity and their role in the Holocene evolution of Central European valleys]. Pr Geogr. 2006;204 (in Polish).

[55] Kozarski S, Rotnicki K. Valley floors and changes of river channel patterns in the North Polish Plain during the Late Wurm and Holocene. Qua Geo. 1977;4:51-93.

[56] Mycielska-Dowgiatto E. Channel pattern during the last glaciation and Holocene in the northern part of the Sandomierz Basin and the middle part of the Vistula valley, Poland. In: Gregory KJ, editor. River chanel changes. Chichester-New York-Brisbane-Toronto: Wiley; 1977.

[57] Starkel L. Role of climatic and anthropogenic factors accelerating soil erosion and fluvial activity in Central Europe. Studia Quaternaria. 2005;22:27-33.

[58] Wyżga B. Impact of the channelization-induced incision of the Skawa and Wistoka Rivers, southern Poland, on the conditions of overbank deposition, Regul Rivers Res Mgmt. 17;2001:85-100.

[59] Wierzbanowski P, Pasieczna A, Stec B, Tomassi-Morawiec H. Geoenvironmental map of Poland (1:50,000), Opole Lubelskie sheet. Warsaw, Poland: Polish Geological Institute - National Research Institute; 2006.

[60] Bąk B, Szeląg A, Bojakowska I, Kwecko P, TomassiMorawiec H, Wojciechowska K. Mapa Geośrodowiskowa Polski w skali 1:50,000. Arkusz Kazimierz Dolny. [Geoenvironmental map of Poland (1:50,000). Kazimierz Dolny sheet.]. Warsaw, 
Poland: Polish Geological Institute - National Research Institute; 2010.

[61] Lis J, Pasieczna A, Strzelecki R, Wołkowicz S, Lewandowski P. Geochemical and radioactivity mapping in Poland. J Geochem Explor. 1997;60:39-53.

[62] Pasieczna A, editor. Atlas geochemiczny Polski 1:2 500000 [Geochemical atlas of Poland (1:2500 000)], Warszawa: Wydawnictwa PIG-PIB [Polish Geological Institute - National Research Institute]; 2012.

[63] Grygar TM, Elznicová J, Kiss T, Smith HG. Using sedimentary archives to reconstruct pollution history and sediment provenance: the Ohře River, Czech Republic. Catena. 2016;104:109-29.

[64] Bojakowska I, Sokotowska G. Heavy metals in the Bystrzyca river flood plain. Geol Q. 1996;40:467-80.

[65] Zgłobicki W, Telecka M, Skupiński S. Assessment of Microscale Variation of Heavy Metal Pollution of the Bystrzyca River Alluvia Downstream from Lublin. Po J Soil Sci. 2017;49:167.

[66] Boszke L, Kowalski A. Mercury fractionation in sediments of the Lower Vistula River (Poland). Oceanological and Hydrobiological. Studies. 2007;36:79-99.

[67] Ciszewski D, Czajka A. Human-induced sedimentation patterns of a channelized lowland river. Earth Surf Process Landf. 2015;40:783-95.
[68] Ważny H, Stenzel P. Badania geochemiczne osadów węglanowych cechsztynu z otworu wiertniczego Grzybnica IG 1 z zastosowaniem analizy czynnikowej-sposób R [An interpretation of geochemical data concerning carbonate Zechstein deposits from borehole Grzybnica IG 1 by means of factor analysis - R mode]. Geol Q. 1976;20:538-50 (in Polish with English summary).

[69] De Saedeleer V, Cappuyns V, De Cooman W, Rudy S. Influence of major elements on heavy metal composition of river sediments. Geol Belg. 2013;13:257-67.

[70] Saulais M, Bedell J-P, Delolme C. Cd, Cu and Zn mobility in contaminated sediments from an infiltration basin colonized by wild plants: the case of Phalaris arundinacea and Typha latifolia. Water Sci Technol. 2011;64:255-62.

[71] Salomons W, Förstner U. Metals in the hydrocycle. Berlin: Springer-Verlag; 1984.

[72] Zwoliński Z. Sedimentology and geomorphology of overbank flows on meandering river floodplains. Geomorphology. 1992;4:367-79.

[73] Merian E, Anke M, Ihnat M, Stoeppler M, editors. Elements and Their Compounds in the Environment. Weinheim: Wiley; 2004.

[74] Kabata-Pendias A, Mukherjee AB. Trace Elements from Soil to Human. Berlin: Springer, Verlag; 2007. 